\title{
Preference for Liquidity of Agents: An Analyse of Brasilian Case
}

\begin{abstract}
This work is meant to show the relevance of the role of money in explaining regional disparities. Points out that before the currency and the banks are incorporated theories of regional development, had two views on regional development, founded on a convergence of unequal growth and divergence in another, where the rates would become increasingly unequal. The literature on the regional economy have given little attention to financial variables and their role in regional development. In this context, the currency has received secondary treatment in the analysis of the regional economy, perhaps in the belief of some theorists in the neutrality of money in the long run, or others who have relied on the assumption of perfect interregional mobility of capital. However, this perspective has been changing in recent years, particularly in post-Keynesian agenda. Thus, we intend to examine the behavior of the public regarding the preference for liquidity in the face of regional characteristics and the financial instability and therefore demonstrate their relevance to explain the differences in regional economic development. To analyze the decision to demand money was used educational and behavioral aspects. The hypothesis that there is a financial concentration in regions with a lower liquidity preference was ratified. For this, the study was developed based on the analysis of units of the Brazilian federation. The database of the Central Bank, and Datasus allowed the use of the formula suggested by the literature pertinent to the theme
\end{abstract}

Keywords: uncertainty, regional development, banks, Brazilian economy, interest rates.

\section{Brazilian economy. Some historical fundaments}

Brazil has five regions: North, Northeast, Central-West, Southeast and South. Historically, since its discovery in 1500, its economic evolution has developed mainly the Northeast, Southeast and South regions, facilitated by their proximity to the coast. The data indicates that the South and Southeast regions were the leaders in the development. The growth in the Northeast was, for a few centuries, attached to agricultural exporting activity, having

a) Faculdade de Economia, Administração e Contabilidade - Universidade Federal de Alagoas, A.C. Simões Av. Lourival de Melo Mota, Bloco 16, $1^{\circ}$ andar Tabuleiro do Martins Maceió Alagoas, Brasil. E-mail:andre_lages@msn.com

b) Universidade Federal de Alagoas, Campus Sertão, Unidade Santana do Ipanema. Rua Prefeito Adeildo Naponuceno Marques, 472 - Monumento - 57500-000. Santana do Ipanema Alagoas, Brazil. E-mail:fabriciorioss@bol.com.br

c) Centro de Estudos Superiores de Maceió, Rua Cônego Machado, 918, Farol CEP: 57051-160, Maceió, Alagoas, Brazil. E-mail:hbfjr@ig.com.br 
sugar as the main product. The sugar cycle growth was supported by slave labour (Africans) and to a lesser by natives (Indians). The Northeast's geography is dominated by called caatinga a common type of vegetation found in semi-arid regions. That condition is characterized by long dry periods with temporary rivers.

Other circumstances have leaded to Japanese as well as European immigration to Sao Paulo (the richest state in Brazil) and other states of the Southeast region of the country. Sao Paulo was a prime producer of coffee. Another flow of immigrants from Italy and Germany also headed to the South Region.

The end of the slavery in the 19th century, the Great Depression in the 1930s and two World Wars created the conditions for the South and Southeast regions to evolve economically faster, and São Paulo concentrating on the industrialization process up to the current day. In this context, it should be emphasized that the end of slavery monetized the Brazilian economy; the Know-how brought by immigrants and the strong expansion of the coffee culture created the seminal conditions for the industrial concentration in Sao Paulo. The other two regions, Central-West and North, with their logistical difficulties, were considered by that time an expanding agricultural frontier. By the end of the 1950s and beginning of the 1960s; it happened the construction of the new capital on Central-West region. The new Capital Brasilia induced a displacement of a considerable part of the Brazilian population to that region.

Table 1

Evolution of the Resident Population, 1991-2010

\begin{tabular}{|c|c|c|c|}
\hline Brazil and Great Regions & 1991 & 2000 & 2010 \\
\hline Brazil & 146825475 & 169799170 & 190755799 \\
\hline North & 10030556 & 12900704 & 15864454 \\
\hline Northeast & 42497540 & 47741711 & 53081950 \\
\hline Southeast & 62740401 & 72412411 & 80364410 \\
\hline South & 22129377 & 25107616 & 27386891 \\
\hline Central-West & 9427601 & 11636728 & 14058094 \\
\hline
\end{tabular}

Source: IBGE - Censos Demográficos, 1991, 2000, 2010.

As Figure 1 shows below, despite development, up to 2010, the Northeast region suffers with the most social problems; here, the greatest percentage of the population earn one-quarter of the official minimum wage in comparison with others regions.

It is important to explain that the Brazilian population was distributed as indicated in Table 1. In the reality. The expansion of the less populated regions still implies a smaller number of banks in those regions; supporting observations from Table 1 and issues around liquidity (monetary). 
Extreme Poverty *Rate in the Brazilian Regions in 1995 and 2008

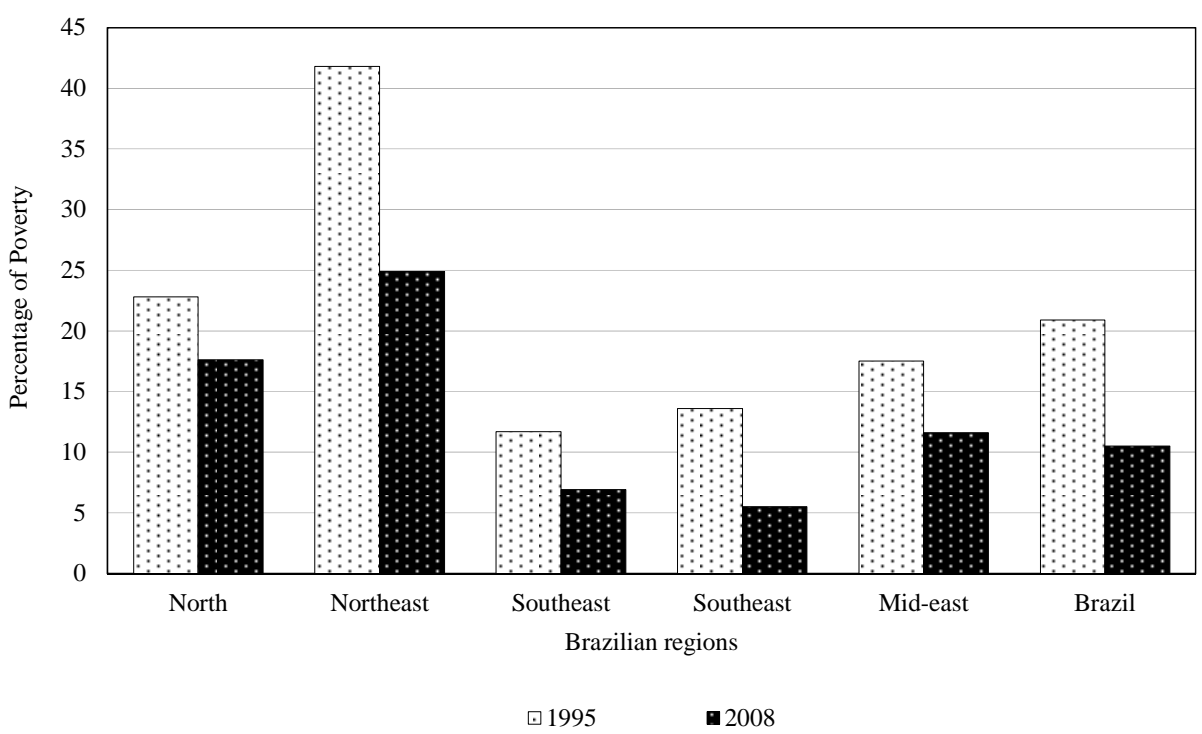

* According to IBGE, extreme poverty rate are families with income around 1/4 of the offical minimum wage. Source: IBGE - PNAD - (IPEA display elaboration).

To conclude, Figure 1 reflects the evolution of historical fundaments to the current day. It will become still more interesting with the Post-Keynesianism approach on sequence.

\section{Uncertainty}

Before the currency and banks were approached by regional development theories, Chick (2006) points out that there were two points of views on regional development -one founded on the convergence of uneven growth rates and another on divergence, where rates become increasingly unequal. The first is guided with the perspective that underdeveloped regions compared with developed regions, would offer higher returns on investments, since, with increasing investment in the given region, returns decrease; thusthose underperforming regions tend to receive greater incentives than the more prosperous areas. The second view holds that prosperous rather than the backward regions would attract investment because progress generates progress, which will increase the inequalities in growth rates.

The literature on the regional economy has given little attention to the financial variables and their role in regional development. In this context, the currency has received secondary treatment in the analysis of the regional economy; some theorists believing, perhaps, in the neutrality of money in the long run, or others who have relied on the assumption of perfect inter-regional mobility of capital, where money flows reproduce only regional differences in real terms (Dow-Fuentes 2006, Nogueira et al. 2010). 
However, that perspective has been changing in recent years, mainly in the Post-Keynesian agenda.

Post-Keynesians, like Keynes, have the currency as a key element in the economic process and do not diminish its influence in the real side of the economic system. Therefore, it is not possible to completely distinguish the money side, and the real side of economy. The coverage given to the currency is based on the idea of a Monetary Production Economy defined by Keynes to explain certain peculiarities of the modern capitalist system. This approach points out that one of the keys caracterísitcas is the process of decision making in uncertain environment. So, the economic agents will define what to do with the money based on their expectations about the future. (Figueiredo-Crocco 2008, Crocco et al. 2011).

From the eighties, in his theoretical and analytical explaination of regional differences, the regional development issue received attention, especially as regards the use of money, because until then, the whole analysis was guided by real variables for this explanation. From Chick, and Dow's essays and contributions $(1982,1987)$, the currency has been considered fundamental in explaining such differences. That moment must be remembered by the construction of an autonomous post-Keynesian theoretical framework in terms of the relationship between the financial system and regional development (FigueiredoCrocco 2008, Ribeiro-Marouvo 2011).

Unlike the neoclassical general equilibrium models and New Keynesians, PostKeynesian theory, in its analysis, takes into account both the supply side as the demand of the regional credit market, using both the development stages of banking as the Keynesian principle of liquidity preference (Dow-Fuentes 2006).

Therefore, the supply and demand for credit are interdependent and affected by a preference for liquidity; these are related to the environment of uncertainty that pervades decision-making process (Nogueira et al. 2010).

Before discussing the concept of uncertainty, its variance from the concept of risk should be clarified; while one is identified by its characteristic of being non-measurable, the other can be measured in quantitative terms (Knight 1921).

According to Keynes (1991, p.274), “.... the dismay and uncertainty as to the future which accompanies a collapse in the marginal efficiency of capital naturally precipitates a sharp increase in liquidity preference - and hence a rise in the rate of interest."

It is worth highlighting that this study will be basically used the demand for vision Keynesian currency exposed in his main book: The General Theory of Employment, Interest, and Money, (1936), and only for the purpose of organizing the argument. it $t$ is recalled that Keynes (1991) defines the demand for money as based on the demand for transaction, precaution and speculation. He also emphasizes that the first reason for demanding currency can be subdivided into two reasons: income-motive and businessmotive. In the first case, it is dependent on income and the normal period receipt and disbursement. For the second case, it makes it clear that the net proceeds are kept in terms of liquidity preference to ensure the time interval they start on the sales receipts. Thus, Keynes (1991) presents sets of reasons to retain liquid resources via the following formula:

$$
\mathrm{M}=\mathrm{M} 1(\mathrm{Y})+\mathrm{M} 2(\mathrm{R})
$$

For analytical simplification, it is considered that M1 represents transaction and precautionary demand for money; where Y (income) represents a independent variable; 
while M2 represents speculation motive, is dependent on and uniquely defines the behaviour of interest (R). Of course, one can point here to a certain reductionism in the reasoning of Keynes, but the purpose is purely didactic

Returning to the central argument, it is noted that the interest rate is a major component with respect to the liquidity preference and consequently, demand for money, since depending on the level, will lead the public to invest or not its cash balances in long-term assets. For Amado1998), the interest rate is the variable that reconciles the desires of savers and investors. According to Figueiredo and Crocco (2008), the interest rate is a monetary phenomenon and acts as a link between money and the real economy.

The behaviour of economic agents, concerning holding or not holding money will depend on its confidence regarding the current economic scenario as well as the expectations regarding the future, which Keynes coined in tha "Animal Spirits":

Keynes (1937 cited by Ferrari Filho-Conceição 2001, p.4), in response to critics of his famous obra4, writes an article entitled "The General Theory of Employment "which defines uncertainty, as follows:

"By 'uncertain' knowledge, let me explain, I do not mean merely to distinguish what is known for certain from what is only probable. The game of roulette is not subject, in this sense, to uncertainty ... Or ... the expectation of life is only slightly uncertain. Even the weather is only moderately uncertain. The sense in which I am using the term is that in which the prospect of a European war is uncertain, or the price of copper and the rate of interest twenty years hence... About these matters, there is no scientific basis on which to form any calculable probability whatever. We simply do not know” (Keynes 1973 cited by Ferrari Filho-Conceição 2001, p.4).

Post-Keynesians, as Keynes, state that in a changeable economy, agents prefer to hold money rather than make spending decisions. As Minsky stated (1975 cited by Ferrari Filho-Conceição 2001), to understand Keynes "it is necessary to understand his sophisticated view ofuncertainty, and the importance of uncertainty in his vision of the economic process. Keynes without uncertainty is something like Hamlet without the Prince".

In Post-Keynesian theory, all credit risk assessments are under the auspices of uncertainty, and the major uncertainty is the "gap" between the borrower and the lender, where the distance can be economic, social, spatial, cultural, etc. (Porteous 1995 cited by Dow-Fuentes 2006). Therefore, the greater the uncertainty, the greater the retention of currency, which in turn, results in a shortage of effective demand, making clear the influence of the currency on the side of real economy

On the demand side for credit, high preference for liquidity will affect the public and their respective portfolio decisions, making them demand more money and less active in the long-term, consequently, increasing liquidity (Crocco et al. 2006).

The hypothesis to be tested is that regions with higher liquidity preference presents a lower bank concentration, being clearly the most peripheral regions. It must be regarded in this case the theoretical and analytical perspective also drawn in Melissa et al. (2007). 
The reduced access to financial services, the lowest level of education, and the less degree of information help to form one negative institutional environment on less developed regions. On the other hand, it should not be forgotten that their business decisions and focus on resources are always more connected and in communion with the more developed regions, where they have usually installed the headquarters of banks

Following this, the paper stresses public behaviour in relation to the demand for money. The study will examine public behaviour in the 26 units of the Brazilian federation and the Federal District, observing signs relating to liquidity preference, and where there is a greater financial concentration, within the group of states and Distrito Federal. Concluding, where the public preference for liquidity is a key variable for distinguishing regional development; certain similarities of regional behaviour linked to the degree of regional development and/or its spatial location, according to a post-Keynesian perspective, can be perceived.

\section{Methodology}

The study was based on the secondary data tract. Collection sources were the sites of the Central Bank of Brazil (BCB) and DATASUS.

From the Central Bank site, information was collected on the number of bank agencies, demand deposits of the private sector and government, time deposits and savings in the period from 2004 to April 2011. DATASUS data on the population, aged 20 to 80 years or more in the 2004-2010 period, was also examined. The relationship is between population (within those limits) and number of bank branches. In Brazil, this is relevant because it should be noted States more developed or less developed is associated or not with such a relationship. That means when the ratio is smaller, implies certain state necessarily be developed? A simple algebraic division was used to assess in which states bank concentration predominates, and how this influences the regional dynamics.

To analyse public behaviour in relation to the allocation of its assets, the preference index for liquidity of the public (PLP) was used; this is presented by Crocco et al (2006) in his article entitled "regional polarization and the financial system", which captures how the public allocates decisions $\mathrm{o}$ its resources among assets or less liquidity, taking into account the degree of uncertainty and the amount of information available in the regions. Accounts used to generate the index were deposit accounts on demand, and savings and time deposits belonging to the liabilities of banks, which provide the public perception of the behaviour in general, and banks as intermediaries. The PLP formula is:

$$
P L P=\frac{D V_{P}+D V_{G}}{D T}
$$

where $\mathrm{DV}_{\mathrm{P}}=$ deposits to private view, $\mathrm{DV}_{\mathrm{G}}=$ government demand deposits, $\mathrm{DT}=$ total deposits (deposits include the private view and the government, term deposits and savings).

The higher the PLP index, the greater the liquidity preference of the public, signalling the public's distrust of the current economic scenario, i.e., they prefer to retain more liquid assets at the expense of less liquid investments in financial assets. 


\section{Results and Discussion}

Looking at Table 1, it can be seen that in the Northeast and North regions, the greater preference for liquidity indices shows that in regions whose economic scenario does not transmit confidence. In this case, people don't invest their financial balances in long-term monetary assets, they will prefer to preserve liquidity. Then, they are on regions characterized by a reduced demand for credit. The uncertainty that permeates these regions is so strong .that even with the policy adopted in recent years by the federal government to increment such regions; the income transfer does not relax the situation. But the North has peculiarities such as: large investments in land belonging to businessmen residing in other parts of the country. In addition, lower population density and number of branches per inhabitant in some states.

Levino and Lages (2008), in analysing the public's attitude towards preference for liquidity in the years 1991, 1996 and 2000, found that the less developed areas showed a greater preference for more liquid assets while in dynamic and prosperous regions, the public would rather hold less liquid assets.

As can be seen, intraregional differences in the case of northeast Brazil, for the state of Ceará presented the lowest index compared to other states of Northeast region, allowing the conclusion that their population has shown reliable behaviour vis-a-vis future expectations. This in turn has led them to apply their resources to long-term assets and to demand more credit to realize investment opportunities. It is extremely important to note that Ceará achieved one of the lowest indexes in Brazil and not only in the Northeast, which allows it to be accredited it as a prosperous state.

On the other hand, it can be seen that the Southeast and South, and, in particular,the District Federal, the political centre, had a very small index; this indicates the regions with a more stable economic scenario, with a consolidated institutional apparatus and educational institutions as government presence. This in turn communicates greater public stability in relation to future expectations. It should be noted that the Federal District is a case in part because of its specific features (Melissa et. al. 2007). These regions are in the reality where are concentrated the most developed states of Brazil; as the numbers on tables show to exactly it.

It is noteworthy that the public had a higher preference for liquidity in 2007 (holding more liquid assets), a period that included international financial insecurity, and generating uncertainty as to the proper functioning of the economy. 
Preference for Public Liquidity (PLP), R\$ 1000 (thousand)

\begin{tabular}{|c|c|c|c|c|c|c|c|c|c|}
\hline State & 2004 & 2005 & 2006 & 2007 & 2008 & 2009 & 2010 & 2011 & 2012 \\
\hline Rondônia & 0.3839 & 0.4073 & 0.3676 & 0.3716 & 0.2776 & 0.2700 & 0.2843 & 0.2183 & 0.2130 \\
\hline Acre & 0.4065 & 0.3631 & 0.4230 & 0.4164 & 0.2385 & 0.2688 & 0.2902 & 0.2354 & 0.3888 \\
\hline Amazonia & 0.3181 & 0.3272 & 0.3518 & 0.3821 & 0.2533 & 0.2814 & 0.2622 & 0.2165 & 0.2188 \\
\hline Roraima & 0.4541 & 0.3873 & 0.3702 & 0.3639 & 0.2614 & 0.2341 & 0.2705 & 0.1635 & 0.3164 \\
\hline Pará & 0.3187 & 0.3052 & 0.3507 & 0.3744 & 0.3037 & 0.2905 & 0.3114 & 0.2587 & 0.2524 \\
\hline Amapá & 0.3339 & 0.3797 & 0.3780 & 0.3704 & 0.2673 & 0.2668 & 0.2848 & 0.2419 & 0.4379 \\
\hline Tocantins & 0.3347 & 0.3769 & 0.3646 & 0.3901 & 0.3395 & 0.3616 & 0.3392 & 0.3011 & 0.2806 \\
\hline Maranhão & 0.3159 & 0.2818 & 0.2980 & 0.3341 & 0.2661 & 0.2624 & 0.2748 & 0.2413 & 0.2297 \\
\hline Piauí & 0.2515 & 0.2453 & 0.2466 & 0.2541 & 0.2157 & 0.2377 & 0.2118 & 0.1806 & 0.1816 \\
\hline Ceará & 0.1276 & 0.1277 & 0.1676 & 0.1787 & 0.1498 & 0.1401 & 0.1321 & 0.1113 & 0.1211 \\
\hline Rio G. do Norte & 0.2389 & 0.2491 & 0.2361 & 0.2625 & 0.2108 & 0.2067 & 0.2086 & 0.1697 & 0.1753 \\
\hline Paraíba & 0.2635 & 0.2626 & 0.2534 & 0.2467 & 0.2265 & 0.2350 & 0.2074 & 0.1720 & 0.1703 \\
\hline Pernambuco & 0.2066 & 0.1976 & 0.2156 & 0.2263 & 0.1718 & 0.1798 & 0.1744 & 0.1491 & 0.1478 \\
\hline Alagoas & 0.2275 & 0.2429 & 0.2404 & 0.2467 & 0.2065 & 0.2392 & 0.2122 & 0.1684 & 0.1624 \\
\hline Sergipe & 0.1923 & 0.2080 & 0.1986 & 0.1949 & 0.1667 & 0.1694 & 0.1742 & 0.1537 & 0.1571 \\
\hline Bahia & 0.2445 & 0.2411 & 0.2455 & 0.2694 & 0.1967 & 0.1770 & 0.1908 & 0.1567 & 0.1638 \\
\hline Minas Gerais & 0.1814 & 0.1906 & 0.1970 & 0.2286 & 0.1630 & 0.1323 & 0.1335 & 0.1137 & 0.1119 \\
\hline Espírito Santo & 0.2010 & 0.1913 & 0.1955 & 0.2007 & 0.1843 & 0.1809 & 0.1890 & 0.1524 & 0.1493 \\
\hline Rio de Janeiro & 0.1856 & 0.1977 & 0.2201 & 0.2643 & 0.1617 & 0.1479 & 0.1461 & 0.1191 & 0.1292 \\
\hline São Paulo & 0.1399 & 0.1395 & 0.1618 & 0.1970 & 0.1087 & 0.1261 & 0.1201 & 0.1055 & 0.1222 \\
\hline Paraná & 0.1685 & 0.1571 & 0.1613 & 0.1787 & 0.1285 & 0.1264 & 0.1264 & 0.1083 & 0.1239 \\
\hline Saint Catarina & 0.2552 & 0.2411 & 0.2473 & 0.2626 & 0.1794 & 0.1762 & 0.1822 & 0.1361 & 0.1446 \\
\hline Rio G. do Sul & 0.1633 & 0.1506 & 0.1611 & 0.1857 & 0.1349 & 0.1347 & 0.1515 & 0.1102 & 0.1095 \\
\hline Mato G. Sul & 0.3084 & 0.2888 & 0.2999 & 0.3054 & 0.2275 & 0.2187 & 0.2220 & 0.1939 & 0.1950 \\
\hline Mato Grosso & 0.4124 & 0.3961 & 0.3718 & 0.3877 & 0.3208 & 0.3056 & 0.3238 & 0.2368 & 0.2409 \\
\hline Goiás & 0.3191 & 0.3072 & 0.3083 & 0.3091 & 0.2502 & 0.2467 & 0.2439 & 0.1976 & 0.2083 \\
\hline Distrito. Federal & 0.1431 & 0.1777 & 0.1357 & 0.1370 & 0.1546 & 0.1295 & 0.1134 & 0.1014 & 0.1233 \\
\hline
\end{tabular}

Source: author's elaboration based on Central Bank data. Exchange rate $€ 1.0=\mathrm{R} \$ 3.12$.

In Table 2, it can be seen that there is more financial concentration exactly in regions with a lower preference for liquidity, depicting which regionsinspire greater confidence for the public. This encourages opportunities for investments, providing the banks in these regions the chance to expand their portfolio of loans, resulting in higher profits. It can be concluded that for the most developed states, the current value of the indicator suggested is lower. This is also explained by the higher level of education existing in these regions, mainly institutions directed to the financial market as well as including the headquarters of some important banks, and big companies. Thisallows a greater number of people over the age of twenty be more able to access financial services, compared to the number of bank branches. These results can be seen in Table 3 . 
Population above 20 years / Number of bank branches

\begin{tabular}{|c|c|c|c|c|c|c|c|c|c|}
\hline State & 2004 & 2005 & 2006 & 2007 & 2008 & 2009 & 2010 & 2011 & 2012 \\
\hline Rondônia & 9.6 & 9.9 & 10.1 & 10.3 & 10.1 & 9.1 & 9.0 & 7.6 & 7.2 \\
\hline Acre & 10.6 & 9.7 & 10.1 & 10.8 & 10.5 & 9.2 & 9.5 & 7.9 & 7.1 \\
\hline Amazon & 12.1 & 12.1 & 12.0 & 11.9 & 12.6 & 11.4 & 11.2 & 10.6 & 10.3 \\
\hline Roraima & 11.1 & 10.8 & 11.0 & 11.8 & 12.5 & 10.0 & 10.2 & 9.0 & 7.4 \\
\hline Pará & 13.2 & 13.0 & 13.1 & 13.5 & 14.1 & 12.9 & 13.0 & 10.6 & 10.6 \\
\hline Amapá & 12.5 & 12.5 & 11.4 & 11.7 & 10.6 & 8.8 & 9.6 & 8.5 & 8.3 \\
\hline Tocantins & 8.9 & 8.8 & 8.8 & 8.6 & 8.6 & 8.1 & 8.5 & 7.5 & 7.4 \\
\hline Maranhão & 14.0 & 14.3 & 14.6 & 14.9 & 15.2 & 14.8 & 14.7 & 12.2 & 12.0 \\
\hline Piauí & 15.1 & 15.3 & 15.0 & 15.5 & 15.8 & 15.6 & 15.9 & 13.2 & 12.2 \\
\hline Ceará & 12.8 & 12.6 & 13.0 & 13.3 & 14.1 & 13.2 & 13.5 & 12.1 & 11.4 \\
\hline Rio Grande do Norte & 13.2 & 12.3 & 12.4 & 12.5 & 13.2 & 12.1 & 12.6 & 11.1 & 10.6 \\
\hline Paraíba & 12.6 & 12.6 & 12.5 & 12.7 & 13.2 & 12.4 & 12.6 & 10.8 & 10.5 \\
\hline Pernambuco & 10.7 & 10.8 & 10.7 & 11.0 & 11.9 & 10.6 & 11.1 & 10.2 & 9.9 \\
\hline Alagoas & 13.4 & 13.5 & 13.6 & 13.8 & 14.4 & 13.4 & 13.3 & 11.0 & 10.1 \\
\hline Sergipe & 7.1 & 7.2 & 7.3 & 7.3 & 7.4 & 7.3 & 7.6 & 7.0 & 6.7 \\
\hline Bahia & 10.8 & 11.1 & 11.0 & 11.2 & 12.2 & 11.2 & 10.8 & 9.7 & 9.0 \\
\hline M. Gerais & 6.6 & 6.8 & 6.8 & 6.9 & 9.0 & 6.9 & 6.9 & 6.4 & 6.3 \\
\hline Espírito Santo & 6.6 & 6.3 & 6.1 & 6.1 & 6.3 & 5.8 & 6.0 & 5.7 & 5.7 \\
\hline Rio de Janeiro & 6.3 & 6.3 & 6.2 & 6.2 & 7.7 & 5.5 & 6.1 & 5.8 & 5.9 \\
\hline São Paulo & 4.7 & 4.7 & 4.7 & 4.6 & 5.2 & 4.2 & 4.4 & 4.3 & 4.4 \\
\hline Paraná & 5.2 & 5.2 & 5.2 & 5.4 & 7.1 & 5.3 & 5.3 & 4.8 & 5.1 \\
\hline Santa Catarina & 4.4 & 4.5 & 4.6 & 4.6 & 4.9 & 4.7 & 4.9 & 4.7 & 4.9 \\
\hline Rio G. do Sul & 5.0 & 5.0 & 5.1 & 5.1 & 5.3 & 4.8 & 4.9 & 4.7 & 4.6 \\
\hline Mato G. do Sul & 6.1 & 6.2 & 6.3 & 6.4 & 6.6 & 6.1 & 6.3 & 5.9 & 6.5 \\
\hline Mato Grosso & 7.0 & 7.0 & 7.1 & 7.1 & 7.5 & 6.7 & 6.8 & 6.6 & 6.8 \\
\hline Goiás & 6.3 & 6.4 & 6.5 & 6.6 & 9.2 & 6.4 & 6.6 & 6.1 & 6.1 \\
\hline Distrito Federal & 4.7 & 4.8 & 4.9 & 4.9 & 5.5 & 4.9 & 5.0 & 4.9 & 4.9 \\
\hline
\end{tabular}

Source: author's elaboration based on Datasus and Central Bank data.

This data indicates that personal turnover is higher in prosperous regions. The spreading of social security policies, such as "bolsa família" does not interfere significantly in mitigating the results.

\section{Conclusion}

From the analysis of regional data, the regions where there is a lower public liquidity preferenceare exactly those with the highest financial concentration, as well as numbers of large companies. These usually require greater educational levels and qualifications. On the other hand, the presence of banksrests on public confidence; in turn, the banks see these great regions as business opportunities and for investment in financial assets due to the higher average purchasing power and greater financial education. For this to occur, there 
is a need for the presence of a number of larg banks to extend credit, which in turn take advantage of the opportunity to increase their loan portfolio and thus generate higher profits.

From this, the hypothesis proposed by the study is ratified. It was dIt is demonstrated that there was an increase in the demand for money in 2007 due to the crisis, as can be seen in the relevant table. This research also state data on the liquidity preference, in short, allow observations and important signalizations about the degree of economic development of a state, region or country.

\section{REFERENCES}

Amado, A. M. (1998): Moeda, financiamento, sistema financeiro e trajetórias de desenvolvimento desigual: a perspectiva pós-keynesiana Revista de Economia Política 18 (1): 76-89.

Banco Central do Brasil (Bacen) (2011): Disponível http://www.bcb.gov.br (accesed: 05 jun. 2011)

Chick, V. (2006): Bancos e regiões: algumas lições da experiência européia In: Crocco, M. A.-Jayme JR, F. G. (Eds.): Moeda e Território: Uma Interpretação da Dinâmica Regional Brasileira pp. 79-92. Autêntica ,Belo Horizonte.

Crocco, M. A.-Cavalcante, A.-Barra, C.-Val, V. (2006): Polarização regional e sistema financeiro In: Crocco, M.-Jayme Jr, F. G. (Eds.): Moeda e Território: Uma Interpretação da Dinâmica Regional Brasileira pp. 231-269., Autêntica, Belo Horizonte.

Crocco, M.-Nogueira, M.-Andrade, C. M. C. de-Amaral, M. L. S. (2011): O Estudo do Gap Regional de Crédito e seus Determinantes, sob uma ótica Pós-Keynesiana Revista Economia 12 (2): 281-307.

Dow, S.-Fuentes, Rodrigues, C. J. (2006): Um "survey” da literatura de finanças regionais In: Crocco, M. A.Jayme JR, F. G. (Eds.): Moeda e Território: Uma Interpretação da Dinâmica Regional Brasileira pp. 39-75., Autêntica, Belo Horizonte.

Ferrari Filho, F.-Conceição, O. A. C. (2001): A Noção de Incerteza nos Pós-Keynesiano e Institucionalistas: Uma Conciliação Possível? Nova Economia 11 (1): 99-122.

Figueiredo, A. T. L.-Crocco, M. (2008): The role of money in the locational theory: a post-keynesian approach Revista Brasileira de Estudos Regionais e Urbanos 2 (1): 33-54.

Keynes, J, M, (1991): The General Thoery of Employment, Interest, and Money Orlando, Harcourt Brace.

Knight, F.H. (1921): Risk, Uncertainty and Profit Houghton Mifflin, New York.

Levino, N. de A.-Lages, A. M. G. (2008): Moeda e Comportamento Territorial dos Agentes Econômicos: Introdução a uma análise regional Enaber, Aracaju.

Nogueira, M.-Crocco, M.-Figueiredo, A. T. L. (2010): Estratégias Bancárias Diferenciadas no Território: O Caso de Minas Gerais Análise Econômic, Porto Alegre 28 (54): 281-311.

Ribeiro, A. C.-Marouvo, C. C. (2011): O Papel da Moeda no Processo de Desenvolvimento Econômico Regional In: XVI Encontro Regional de Economia, Fortaleza. 


\section{ANNEX}

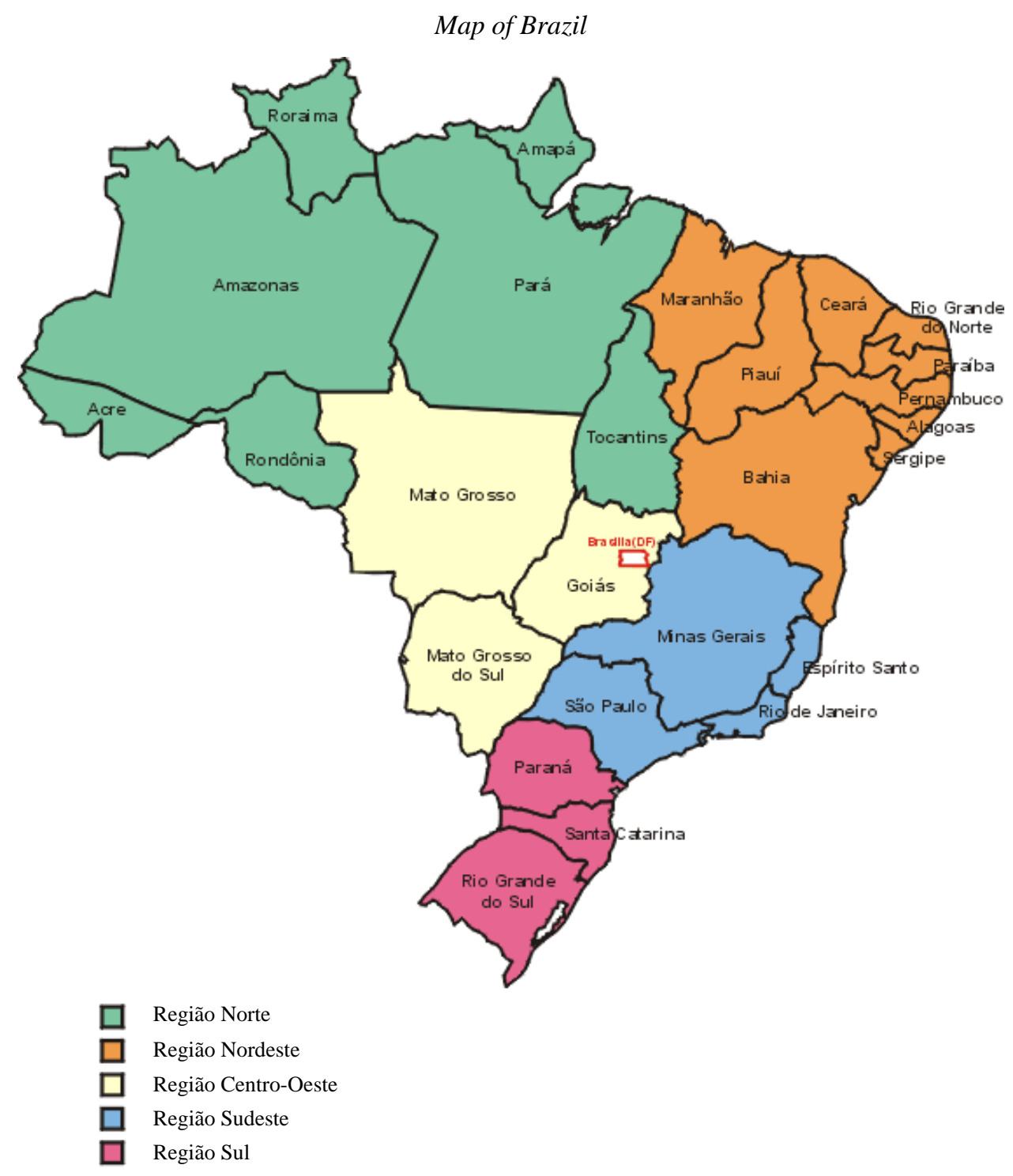

